\title{
Seasonal effects of irrigation on land-atmosphere latent heat, sensible heat, and carbon fluxes in semiarid basin
}

\author{
Yujin Zeng ${ }^{1,2}$, Zhenghui Xie ${ }^{1}$, and Shuang Liu ${ }^{1,2}$ \\ ${ }^{1}$ State Key Laboratory of Numerical Modeling for Atmospheric Sciences and Geophysical Fluid Dynamics, \\ Institute of Atmospheric Physics, Chinese Academy of Sciences, Beijing 100029, China \\ ${ }^{2}$ College of Earth Science, University of Chinese Academy of Sciences, Beijing 100049, China
}

Correspondence to: Zhenghui Xie (zxie@lasg.iap.ac.cn)

\author{
Received: 10 October 2016 - Discussion started: 17 October 2016 \\ Revised: 18 January 2017 - Accepted: 30 January 2017 - Published: 21 February 2017
}

\begin{abstract}
Irrigation, which constitutes $\sim 70 \%$ of the total amount of freshwater consumed by the human population, is significantly impacting land-atmosphere fluxes. In this study, using the improved Community Land Model version 4.5 (CLM4.5) with an active crop model, two high-resolution $(\sim 1 \mathrm{~km})$ simulations investigating the effects of irrigation on latent heat $(\mathrm{LH})$, sensible heat $(\mathrm{SH})$, and carbon fluxes (or net ecosystem exchange, NEE) from land to atmosphere in the Heihe River basin in northwestern China were conducted using a high-quality irrigation dataset compiled from 1981 to 2013. The model output and measurements from remote sensing demonstrated the capacity of the developed models to reproduce ecological and hydrological processes. The results revealed that the effects of irrigation on $\mathrm{LH}$ and $\mathrm{SH}$ are strongest during summer, with a LH increase of $\sim 100 \mathrm{~W} \mathrm{~m}^{-2}$ and a SH decrease of $\sim 60 \mathrm{~W} \mathrm{~m}^{-2}$ over intensely irrigated areas. However, the reactions are much weaker during spring and autumn when there is much less irrigation. When the irrigation rate is below $5 \mathrm{~mm} \mathrm{day}^{-1}$, the LH generally increases, whereas the $\mathrm{SH}$ decreases with growing irrigation rates. However, when the irrigation threshold is in excess of $5 \mathrm{~mm} \mathrm{day}^{-1}$, there is no accrued effect of irrigation on the $\mathrm{LH}$ and SH. Irrigation produces opposite effects to the NEE during spring and summer. During the spring, irrigation yields more discharged carbon from the land to the atmosphere, increasing the NEE value by $0.4-0.8 \mathrm{gC} \mathrm{m}^{-2} \mathrm{day}^{-1}$, while the summer irrigation favors crop fixing of carbon from atmospheric $\mathrm{CO}_{2}$, decreasing the NEE value by $\sim 0.8 \mathrm{gC} \mathrm{m}^{-2} \mathrm{day}^{-1}$. The repercussions of irrigation on land-atmosphere fluxes are not solely linked to the irrigation amount, and other parameters (especially the temperature) also control the effects of irrigation on $\mathrm{LH}$, $\mathrm{SH}$, and NEE.
\end{abstract}

\section{Introduction}

Irrigation consumes most of the freshwater exploited by the global human population (Douglas et al., 2006). According to statistics obtained from the Food and Agriculture Organization (FAO) of the United Nations, about 2722 billion $\mathrm{m}^{3}$ or $70 \%$ of the total global anthropogenic water extraction was consumed by agricultural irrigation in 2007. In Asia and Africa, where agriculture contributes the most to gross domestic product (GDP), irrigation becomes more important and consumes more than $80 \%$ of total exploited freshwater (Oweis and Hachum, 2006).
Anthropogenic carbon emissions from fossil fuel combustion have already primarily changed the concentration of carbon dioxide in the atmosphere, leading to an increase in global temperatures (Cox et al., 2000; Bindoff et al., 2013). Decades of large-scale and intensive farmland irrigation may also have greatly influenced the land-atmosphere water budget (Vörösmarty and Sahagian, 2000). Theoretically, all major land-to-atmosphere fluxes are directly or indirectly impacted by irrigation (Chen and Xie, 2010). Irrigation water can moisten the soil root zones and alleviate the water stress on crops, generating more water consumption by ground evaporation, vegetation evaporation, and crop transpiration (collectively called evapotranspiration, or ET) to 
be returned to the atmosphere (Kendig et al., 2000; Yu et al., 2014). This results in a direct augmentation of the latent heat flux (LH) from land to atmosphere (Haddeland et al., 2006). In addition, the irrigation changes the partitioning of net radiation available at the surface into $\mathrm{LH}$ and sensible heat (SH) (Bowen ratio) (Meijninger and De Bruin, 2000). Vertical carbon fluxes are also affected. When subjected to less water stress related to irrigation, crops grow more vigorously and sequester more carbon from atmospheric $\mathrm{CO}_{2}$ during the growth season (Vitousek et al., 1997), inducing a negative change in carbon flux (also called net ecosystem exchange, or NEE in ecosystem ecology) between land and atmosphere. The NEE variation is very important because it is directly linked to crop yields. From a larger perspective, the NEE is related to greenhouse gases and global warming (Xie et al., 2014). The contribution of agricultural irrigation to other land-atmosphere fluxes, such as momentum fluxes (which are closely related to crop height) and the nitrogen and oxygen fluxes that accompany the NEE, has also been demonstrated by previous studies (Forster and Graf, 1995; Scheer et al., 2008). When vertical fluxes are modified, other atmospheric variables (e.g., air temperature, precipitation, carbon-nitrogen concentration) may vary correspondingly at the local and regional scales and may even be globally changed through atmospheric circulation (Chen and Xie, 2012). Therefore, the quantification of the impacts of irrigation on land-atmospheric fluxes will improve our knowledge of how human disturbances impact the natural water, energy, and carbon cycles and will also contribute to preventing the potential destruction of the environment and resources caused by excessive water irrigation.

However, since the effects of irrigation differ depending on the location and the crop response to irrigation varies during distinct growth phases, it is not easy to thoroughly evaluate the effects of irrigation on land-atmosphere fluxes. Several investigations confirmed the repercussions of irrigation on land-atmosphere fluxes (Lobell et al., 2008; Leng et al., 2013; Cook et al., 2011, 2015; Puma and Cook, 2010). Boucher et al. (2004) conducted simulations based on the general circulation model (GCM) to quantify the effects of irrigation on the atmospheric water vapor content on a global scale. They revealed that the water vapor flux from irrigation could reach as high as $300 \mathrm{~kg} \mathrm{~m}^{-2} \mathrm{yr}^{-1}$ in eastern China and northern India, where irrigation was most intensive. Sacks et al. (2009) conducted a land-atmosphere coupling simulation using the Community Atmosphere Model (CAM) and the Community Land Model (CLM) to study the global impact of irrigation on sensible heat flux and near-surface temperature. They demonstrated that irrigation influenced the vapor flux and also reduced the sensible heat flux over the northern midlatitude regions (e.g., the central USA, southeast China, and portions of southern and southeast Asia), thus cooling the global average temperature by $\sim 0.5^{\circ} \mathrm{C}$. These findings were corroborated by Pokhrel et al. (2012) using the Minimal Advanced Treatments of Surface Interaction and Runoff
(MATSIRO) land model combined with the Gravity Recovery and Climate Experiment (GRACE) satellite observations. The authors demonstrated that irrigation produced a maximum increase of $50 \mathrm{~W} \mathrm{~m}^{-2}$ in latent heat flux averaged over the months of June and August. Leng et al. (2014, 2015) focused on the groundwater-fed irrigation and incorporated a groundwater withdrawal scheme into the CLM4. The authors calibrated and ran the coupled model over the USA and the globe, and underscored the importance of local hydrologic feedbacks in governing hydrologic response to anthropogenic change.

The global investigations described above can define the critical zones affected by irrigation; however, some shortcomings are apparent. First, common methods of large-scale modeling use soil moisture or crop ET deficiencies to estimate the temporal and spatial distributions of irrigation. However, in reality, the determination of the irrigation location is much more complicated and locally dependent. The water allocation is related to the water demand and available water, but it also closely involves the local water policy and residents' habits and customs. Secondly, in reality, irrigation does not occur in one spatially contiguous layer of moisture but rather as a patchwork of individual fields covering hundreds of hectares. The large-scale modeling often displays a resolution of $0.1^{\circ}$ to $1.0^{\circ}(10$ to $100 \mathrm{~km}$ at the Equator), which is too large to describe the irrigation in a patchwork distribution. Several recent studies have focused on the consequences of irrigation on a regional scale, such as in South Asia (Shukla et al., 2014) or on the North China Plain (Zou et al., 2014, 2015). However, the model grid size $\left(2^{\circ}\right.$ and $\left.25 \mathrm{~km}\right)$ is still unsatisfactory to capture the feature of each irrigated patchwork. Zeng et al. (2016) incorporated the schemes describing groundwater lateral flow and human water regulation into CLM4.5 and conducted highresolution (about $1 \mathrm{~km}$ ) simulations to quantify the effects of human water-related activities on land processes. It showed impressive results that land models could be used in highresolution and basin-scale modeling. However, the prognostic carbon-nitrogen cycle and crop model in CLM4.5 were not active in Zeng et al. (2016), which give its' results a high-level of uncertainty and exclude impacts of irrigation on carbon cycle. To overcome the difficulties above and take further steps, our study focused on a typical semiarid irrigated basin, the Heihe River basin situated in northwestern China, and conducted a high-resolution simulation $(1 \mathrm{~km})$ using the state-of-art CLM4.5 with active carbon-nitrogen cycle and crop model, and incorporating a high-quality irrigation dataset to quantify the impacts of irrigation on the $\mathrm{LH}$, $\mathrm{SH}$, and NEE parameters from land to atmosphere. The objectives of our study are to (1) test the model performance of the CLM4.5 under the active carbon-nitrogen cycle, crop model, and high-quality irrigation input data, (2) quantify the effects of irrigation on the LH, SH, and NEE parameters, and (3) decipher the relationship between irrigation and the changing fluxes. In addition to the scientific objectives above, 


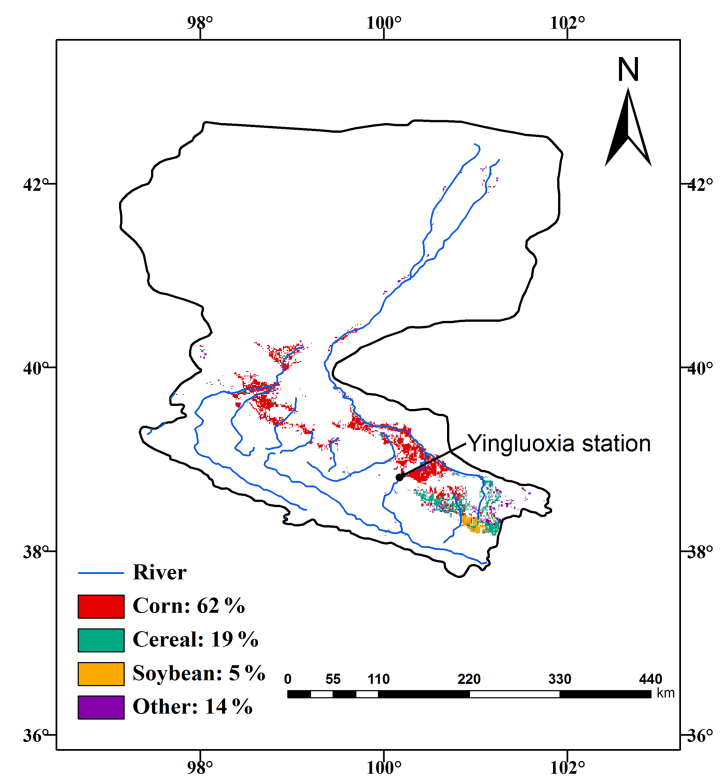

Figure 1. Study area and location of the Heihe River basin in northwestern China, the spatial pattern of crops in the basin, and the location of the Yingluoxia hydrologic station.

our work is a further step in producing a high-resolution land surface simulation model that represents crop growth on a basin scale. The model can bring valuable support to future investigations aiming to improve the representation of hydrological and ecological processes in Earth system models (Clark et al., 2015a, b, c; Fan, 2015).

Background information related to the domain of study is given in Sect. 2. The model is introduced in Sect. 3, including the data sources for irrigation and the experimental design. Sect. 4 presents the results of the simulations, while the discussion and conclusions are given in Sect. 5.

\section{Domain of study}

The Heihe River basin is the second largest inland river basin located in China (Fig. 1). The basin spans an area from $96^{\circ} 42^{\prime}$ to $102^{\circ} 00^{\prime} \mathrm{E}$ longitude and from $37^{\circ} 41^{\prime}$ to $42^{\circ} 42^{\prime} \mathrm{N}$ latitude (Lu et al., 2003). The area covered by the basin is about $116000 \mathrm{~km}^{3}$ and lies east of the Shule River and west of the Shiyan River basin (Chen et al., 2005). The Heihe River basin upstream and middle reaches sit in a semiarid area, whereas the downstream reaches retain an arid climate all year round.

The Heihe River basin is characterized by different geomorphologic features. From south (upstream) to north (downstream) we observed the Qilian Shan, Hexi Corridor, and Alxa Gaoyuan. The climatic condition and water resource distribution also differ. In the upstream basin where mountainous areas predominate, the average precipitation is $\sim 200 \mathrm{~mm} \mathrm{yr}^{-1}$ at elevations ranging from 2000 to $3000 \mathrm{~m}$, and $\sim 500 \mathrm{~mm} \mathrm{yr}^{-1}$ from 3000 to $5500 \mathrm{~m}$. The high-altitude region is the main water resource of the entire basin (Wu et al., 2010). In the middle reaches of the basin, where the elevation shows a north-south decrease from 2000 to $1000 \mathrm{~m}$, the precipitation diminishes correspondingly from $200 \mathrm{~mm}$ year ${ }^{-1}$ to less than $100 \mathrm{~mm} \mathrm{yr}^{-1}$ (Li et al., 2001). The middle reaches contain sufficient light-heat resources and are a major area of crop cultivation. Corn is the main cultivated crop, occupying $62 \%$ of the arable land. Barley, wheat, and cotton are also important crop types in the Heihe River basin. The scarce precipitation forces the intense extraction of irrigation water from the main stream of the Heihe River. The exploitation of groundwater in the middle reaches has also increased during recent years to reduce the removal of surface water and maintain a base flow for the downstream environment, in concordance with the water policy of the "water diversion scheme" set by the local government in 1997. The downstream area of the basin is formed by the Alxa High plain at an altitude of about $1000 \mathrm{~m}$. The plain is extremely arid, characterized by only $42 \mathrm{~mm} \mathrm{yr}^{-1}$ of annual precipitation based on data from local meteorological stations (Qi and Luo, 2005).

\section{Model description and experimental design}

\subsection{Community land model 4.5}

The CLM4.5 used in this study was developed by the National Center for Atmospheric Research, USA (Lawrence et al., 2011; Oleson et al., 2013). The model constitutes the land component of the Community Earth System Model (CESM) 1.2.0 (Gent et al., 2011; Hurrell et al., 2013). The CLM4.5 simulates the exchange of radiation, momentum, heat, and water vapor flux between land and the atmosphere. It also models hydrologic processes (including precipitation interception, soil infiltration, runoff production, soil water movement, aquifer recharge, and snow dynamics), vertical energy transfer within soil and snow, and other bio-geophysical processes (Lindsay et al., 2014). Important biogeochemical processes, which include the carbon-nitrogen cycles, vegetation photosynthesis and respiration, phenology, decomposition, and fire parameterization (among others), are also explicitly defined by the CLM4.5.

Additionally, the CLM4.5 incorporated an interactive crop management model based on the Agro-IBIS crop module. The latter simulates crop growth and its effects on land processes. The model sets specific parameters for corn, temperate cereals, and soybeans and includes a crop phenology algorithm for different growth phases of planting, leaf emergence, grain fill, and harvest. The carbon-nitrogen distribution in each crop tissue (leaf, stem, root, and grain) is also different to that of natural vegetation. The crop module in CLM4.5 has been thoroughly tested by Levis et al. (2012) and was found to be highly performative for simulating the carbon fluxes from land to atmosphere. 
CLM4.5 is renowned for its ability to model large-scale events, especially in reproducing land-atmosphere fluxes. However, few studies to date tested the model on smallerscale cases with a high resolution rather than $1 \mathrm{~km}$. In theory, since the bio-geophysical and biogeochemical aspects of the model are relatively complex, CLM 4.5 will be suitable for small-scale events if the input data are comprehensive enough. This study thus benefits from the complexity of the model and the numerous high-resolution input data available for the Heihe River basin to demonstrate the adequacy of the land model at a small scale.

In this study, we adopted a modified version of CLM4.5, which was improved by Zeng et al. (2016). This version of CLM4.5 was coupled with a groundwater lateral flow scheme, which enables the model to explicitly capture the water table pattern following terrain-driven lateral flow. A scheme describing human water regulation was also included in the model. More detailed information about the improved CLM4.5 can be found in Zeng et al. (2016).

\subsection{Brief introduction for the irrigation module of the improved CLM4.5}

To investigate the irrigation effects on land-atmosphere fluxes, the irrigation scheme in the land model is a key part. The original version of CLM4.5 includes the option to irrigate croplands. However, this version is not appropriate for our fine-scale study because (1) the resolution of the original irrigation database in CLM4.5 is 15 arcmin (about $0.083^{\circ}$ at the Equator), which is too coarse and not precise enough for our high-resolution ( $1 \mathrm{~km}$ or $0.0083^{\circ}$ at the Equator) modeling, (2) the irrigation module does not include groundwater extraction, which could impact the land-atmosphere fluxes by modifying the water table level and soil moisture content (Di et al., 2011; Xie et al., 2012), and (3) the irrigation water included in CLM4.5 is removed from local runoff sources rather than from nearby rivers. This procedure does not reflect the real water diversion process, especially when model resolution is fine enough to distinguish the river grid cells from others. Although some key works conducted by Leng et al. $(2014,2015)$ have extended the CLM's ability in modeling anthropogenic groundwater exploitation, the officially public version of CLM4.5 does not include such important human activity at this time.

The improved CLM4.5 developed by Zeng et al. (2016, 2017) incorporated an irrigation scheme that could settle the aforementioned points. The diagram of the complete module is presented in Fig. 2. In the model, the process of groundwater withdrawal for irrigation is described as

$$
\left\{\begin{array}{l}
d^{\prime}=d+\frac{Q_{g} \times \Delta t}{s} \\
W^{\prime}=W-Q_{\mathrm{g}} \times \Delta t
\end{array},\right.
$$

in which $\Delta t(T)$ is the time step of the model, $s$ is the aquiferspecific yield provided by CLM4.5, $Q_{\mathrm{g}}(L / T)$ is the ground-

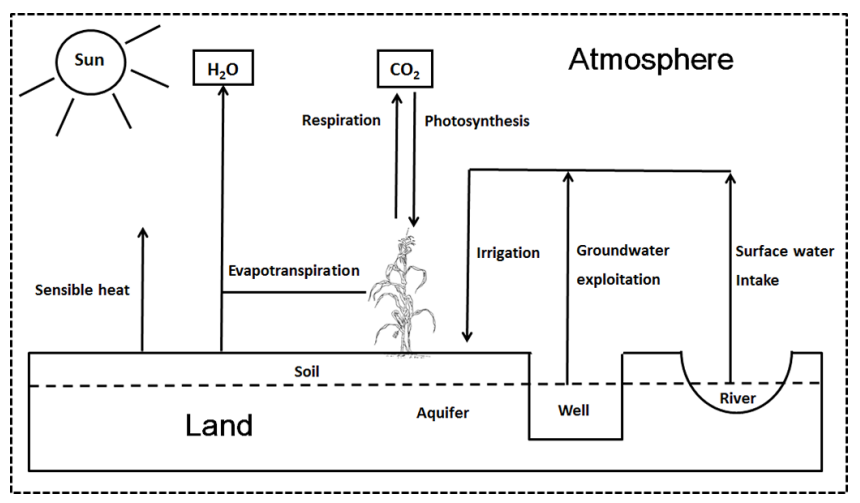

Figure 2. Diagram of the irrigation module showing how irrigated water impacts land-atmosphere fluxes.

water pumping rate, $d(L)$ and $d^{\prime}(L)$ are, respectively, the simulated groundwater table depth before and after accounting for anthropogenic groundwater exploitation, and $W(L)$ and $W^{\prime}(L)$ are, respectively, the simulated aquifer water storage before and after accounting for anthropogenic groundwater exploitation. The surface water diversion for irrigation in the model is described as

$S^{\prime}=S-Q_{\mathrm{s}} \times \Delta t$,

in which $Q_{\mathrm{s}}(L / T)$ is the anthropogenic surface water intake, and $S(L)$ and $S^{\prime}(L)$ are, respectively, the original surface water stored in a river (as calculated by CLM4.5 coupled with the River Transport Model) and the updated value after subtracting the anthropogenic demand. If the local surface water intake $Q_{\mathrm{s}} \Delta t$ is greater than local surface water storage $S$, the deficit is satisfied by extracting surface water from nearby grid cells. The water abstracted from aquifer and river is applied directly to the ground surface, bypassing the canopy interception as

$Q_{i}^{\prime}=Q_{i}+Q_{\mathrm{g}}+Q_{\mathrm{s}}$,

in which $Q_{i}(L)$ and $Q^{\prime}{ }_{i}(L)$ are, respectively, the simulated water input into the soil surface before and after accounting for anthropogenic water application. The irrigation water losses to runoff and aquifer would be calculated automatically by CLM4.5 with the updated water input to soil $Q^{\prime}{ }_{i}$, which combines both precipitation and irrigation. $Q_{\mathrm{g}}$ and $Q_{\mathrm{s}}$ are determined by the external high-quality irrigation dataset, which will be described in Sect. 3.3.

The irrigation water would moisten the soil and operate on crops, alleviating the water stress occurring in semiarid areas and improving the conditions of growth. This in turn would subsequently modify the water, energy, and carbon fluxes of the land and the atmosphere. The irrigated water is distributed uniformly throughout the day, reproducing the process of flooding irrigation. It should be noticed that the water balance is closed in the model because the total withdrawal amount of the water (from surface and underground) is equal to the whole consumption in irrigation. 


\subsection{Irrigation database for the Heihe River basin}

One advantage of basin-scale modeling is the application of precise irrigation data provided by local water departments to reduce the uncertainties from input data. We applied the Monthly Irrigation Datasets (MID) provided by the Cold and Arid Regions Science Data Center (CARSDC) at Lanzhou to the model input. The MID is a high-resolution ( $30 \operatorname{arcsec}$ or $1 \mathrm{~km}$ ) monthly gridded dataset collected from 1981 to 2013. The database differentiates the irrigation water provided by surface water and groundwater. The MID was assembled by collecting a large number of irrigation statistics from local administrations, historical literature, and farmland surveys at the province level, and by downscaling the collected data to $1 \mathrm{~km}$ grid cells using the retrieved ET from the remote sensing dataset ETWatch (Wu et al., 2012). Other data sources were referenced when the dataset was created. The MID has been successfully verified by comparison with independent databases provided by the Water Resource Bullet of Gansu Province and from statistics contributed by several irrigation districts. Figure 3 shows the MID spatial distribution of the irrigation rate occurring during the four seasons. The irrigation is principally applied to farmland associated with the middle reaches of the Heihe River basin, with summer being the season with the most intensive irrigation. Almost no irrigation occurs during winter.

Since the irrigation rate was prescribed before the simulations, it does not interact with the crop water stress (reflected by soil moisture or crop transpiration) in the model. This is one of the disadvantages of our simulation because in reality the irrigation rate is low when soil water is rich. Arguably, the irrigation rate from MID was based on the actual evapotranspiration and historical irrigation records, so in fact it accounted for the water stress in an implicit way. Moreover, on the local level, in addition to the crop water stress, the water supply from upstream, water policy, and residents' habits and customs also play key roles in the determination of irrigation rate; therefore, it is reasonable to apply an external high-quality dataset to quantify irrigation in the highresolution simulations.

\subsection{Experimental design}

Two simulations were conducted using the improved CLM4.5 (Zeng et al., 2016) in the Heihe River basin. The first simulation named "CTL" forms the control simulation assuming no irrigation is applied, and the second simulation named "IRR" includes the effects of the irrigation dataset referred to in Sect. 3.3. The simulation period was set from 1981 to 2013, corresponding to a period during which the input irrigation dataset was collected, with a time step of $1800 \mathrm{~s}$. The simulation spatial resolution was fixed at $30 \operatorname{arcsec}\left(0.0083^{\circ}\right)$. To satisfy the high-resolution process, we replaced the CLM4.5 land cover data with the Multi-source Integrated Chinese Land Cover map available at a $1 \mathrm{~km}$ resolution (Ran et al., 2012). We used the Heihe Watershed Allied Telemetry Experimental Research (HiWATER) land cover map with $30 \mathrm{~m}$ resolution (Li et al., 2013; Zhong et al., 2014) to identify the specific crop types (corn, cereals, soybean, or others) from each crop grid. The soil dataset (content of clay, silt, sand, and organic matter) included in the CLM4.5 was replaced by the China Soil Characteristics Dataset with a $1 \mathrm{~km}$ resolution (Shangguan et al., 2012). The databases were provided by CARSDC (http: //westdc.westgis.ac.cn/). It should be noticed that in the highresolution surface dataset, only one kind of landscape (e.g., bare soil, different plant function types, lake, or urban) existed within a model grid cell, indicating that most of the subgrid structure was not applied. To obtain the impacts of irrigation on the crop carbon fluxes, the fully prognostic carbon and nitrogen cycle modules accompanied by the interactive crop management module in CLM4.5 were activated. The atmospheric forcing dataset was acquired from the Data Assimilation and Modeling Center for Tibetan Multi-spheres, Institute of Tibetan Plateau Research (ITP) of the Chinese Academy of Sciences (Yang et al., 2010), with a spatial resolution of $0.1^{\circ}$ and a temporal resolution of $3 \mathrm{~h}$. Before beginning the proper simulations, the CLM was run for a 700-year period (also using the ITP atmospheric forcing dataset, but in cycle, without irrigation) to produce model variables attaining their natural equilibrium state (especially for each carbon and nitrogen pool) following the CLM user guide (Kluzek, 2012). The CTL and IRR simulations were then computed using the initial files generated by the 700-year spin-up.

\section{Results}

\subsection{Validation}

The performance of the implemented model has been tested in Zeng et al. (2016) by multiple comparisons with observations from the eddy covariance (EC) and automatic weather (AW) systems, groundwater wells, and remote sensing. In this study, we additionally compared our simulated results with NASA's Gravity Recovery and Climate Experiment (GRACE) satellite data (Tapley et al., 2004), observed streamflow data, retrieved ET, and net primary productivity (NPP) acquired from remote sensing.

Figure 4 shows the basin-averaged terrestrial water storage (TWS) from GRACE and the modeled TWS from CTL and IRR in the period of 2002-2013 when GRACE data were available. From the picture, both CTL and IRR captured the general variations of TWS shown by GRACE. However, their linear trends were different. The results from CTL show a minor regression coefficient of $-0.10 \mathrm{~cm} \mathrm{yr}^{-1}$, while they show $-0.19 \mathrm{~cm} \mathrm{yr}^{-1}$ in the IRR, much closer to the $-0.20 \mathrm{~cm} \mathrm{yr}^{-1}$ displayed by the GRACE data. This comparison demonstrated that irrigation from groundwater exploitation has significantly depleted the terrestrial water storage in the basin, 


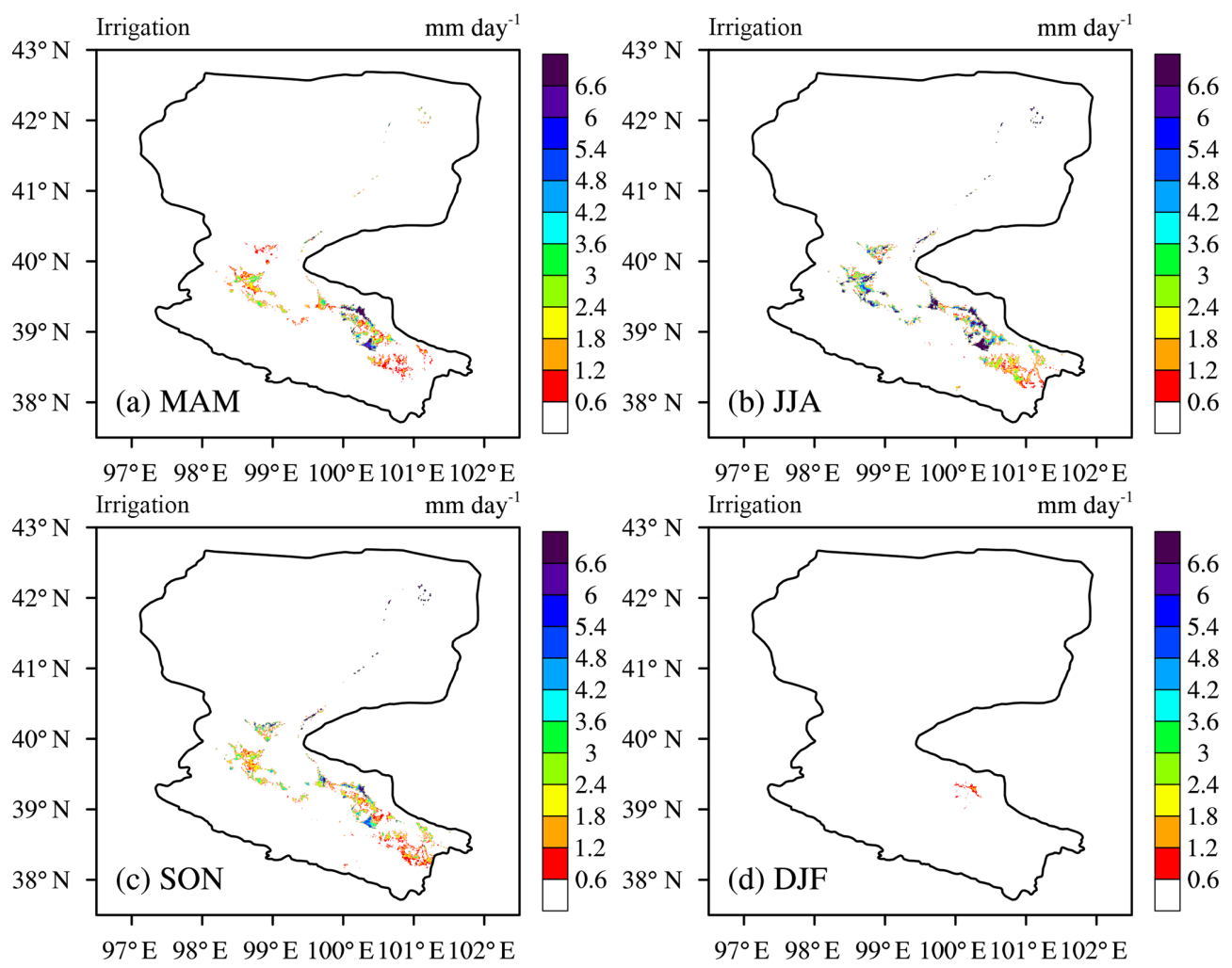

Figure 3. Climatological spatial distribution of the irrigation rate from monthly irrigation datasets in (a) spring, (b) summer, (c) autumn, and (d) winter from 1981 to 2013 .

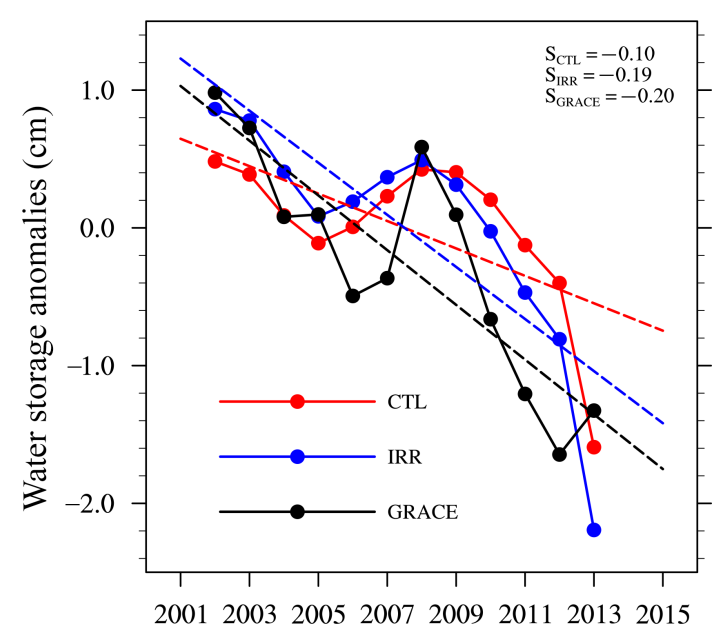

Figure 4. Basin-averaged terrestrial water storage (TWS) from GRACE and the modeled TWS from CTL and IRR in the period of 2002-2013.

and this effect could be reproduced when groundwater irrigation was included in the model.

Then we compared our modeled streamflow with the observations. Although the interesting variables in this study are the energy and carbon fluxes, the valid streamflow can indicate that the model takes the right amount of water from the river for irrigation. The gauged discharge was obtained from the Yingluoxia hydrologic station located in Yingluoxia Gorge, the midstream inlet of the Heihe River (shown in Fig. 1). The discharge data were provided by Liu et al. (2016). Figure 5 shows the time series for the modeled and observed daily streamflow over Yingluoxia Gorge from 2002 to 2004. It shows that our model can generally truly reproduce the magnitude and seasonal variability of the discharge, and the correlation coefficient is about 0.7. However, the error between the simulation and observation was obvious. It indicates that the River Transport Model of CLM4.5 could be substantially improved and the reservoirs should be included. Taking into consideration that the subjects in the study are the land-atmosphere fluxes rather than streamflow and the river only plays the role of water source for irrigation in the simulation, the modeling skill at this time could be accepted.

We then compared the modeled ET with the remote sensing dataset from ETWatch (Wu et al., 2012). Although Zeng et al. (2016) has done similar work, this comparison is different because the modules of prognostic carbon-nitrogen cycles and interactive crop management in CLM4.5 were active and the input irrigation data were much more realistic than those used in Zeng et al. (2016). The ETWatch retrieves actual ET using multisource remote sensing data and multiple inversion algorithms such as TSEB (Norman et al., 1995; 


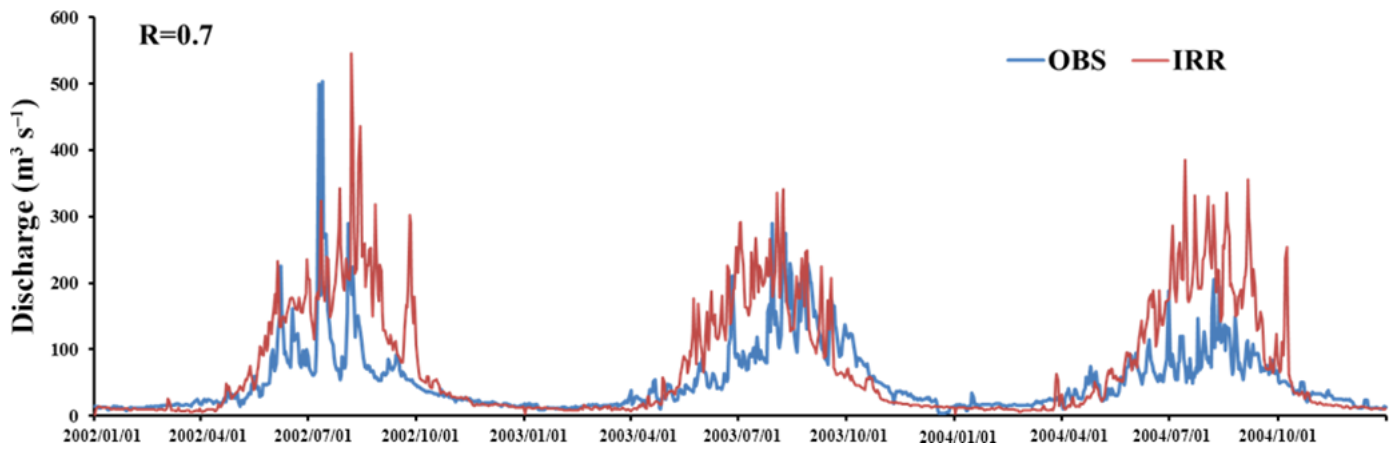

Figure 5. Time series for the modeled and observed daily streamflow over Yingluoxia Gorge from 2002 to 2004.

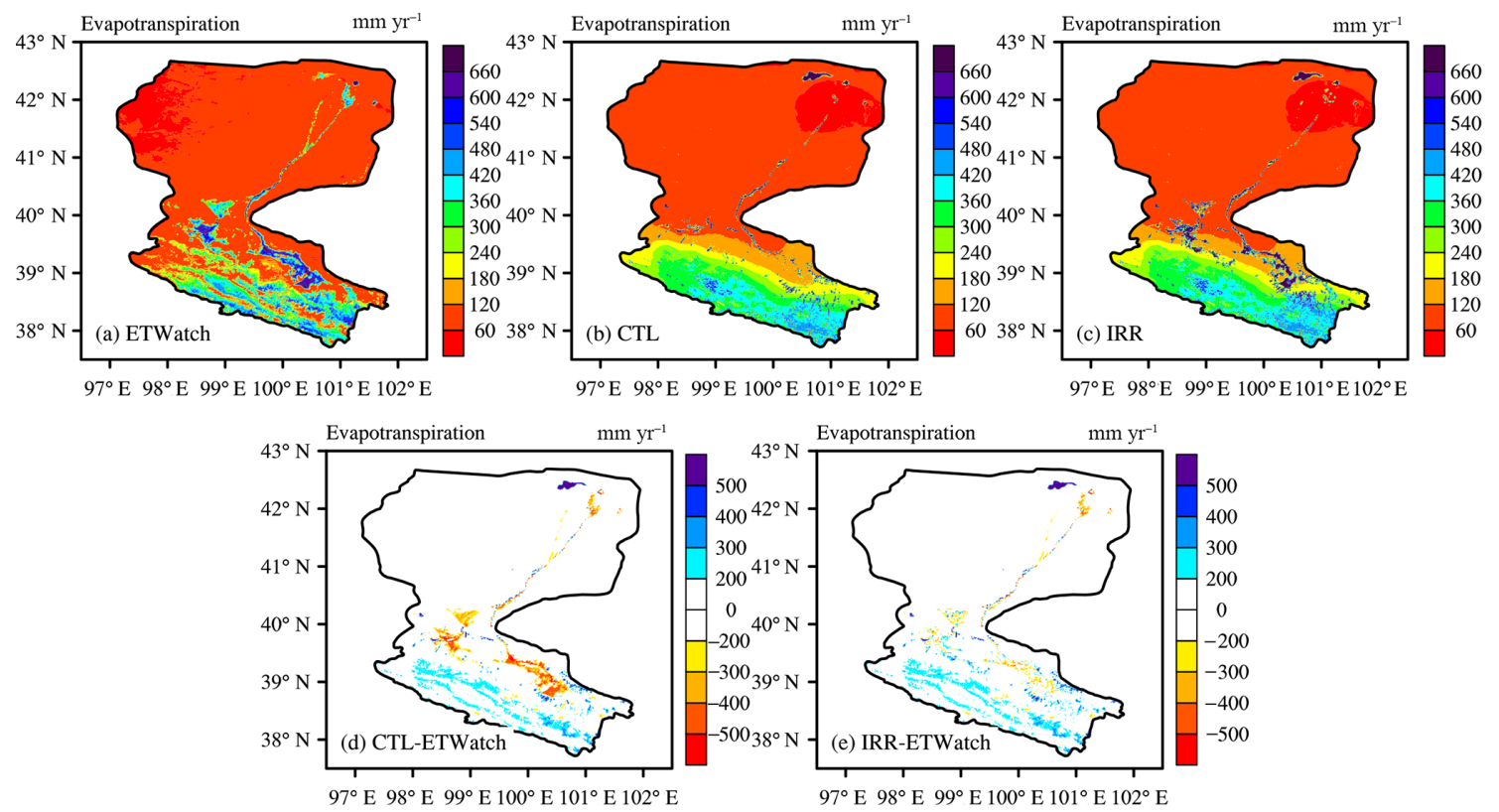

Figure 6. Climatological evapotranspiration distribution from 2000 to 2003 over the Heihe River basin obtained from (a) ETWatch, (b) CTL, (c) IRR, (d) CTL ETWatch, and (e) IRR ETWatch.

Anderson et al., 1997), SEBS (Su, 2002), and SEBAL (Bastiaanssen et al., 2005). The remote sensing data from ETWatch have been independently verified using various procedures on different cultivated fields and landscapes. Figure 6 shows the climatologic ET distribution obtained from 2000 to 2003 by ETWatch, CTL, and IRR over the Heihe River basin. The period was selected based on the duration of the ETWatch. Figure $6 \mathrm{a}$ features a contiguous area with a high-level ET obtained by ETWatch along the middle reaches of the Heihe River. The high-level ET results from intensive irrigation (see Fig. 3). This pattern did not appear in the CTL results (Fig. 6b). However, it was reflected in the IRR results when irrigation was included (Fig. 6c). This again demonstrates the importance of incorporating irrigation in the studies of the land-atmosphere water vapor flux (latent heat flux). South of the Heihe River basin, in the upstream reaches where arctic grass grows without irrigation, both the CTL and IRR poorly captured the ETWatch ET pattern, indicating that the CLM needs improvement for carbon-water cycle simulations in cold regions.

We then compared our NPP results derived from remote sensing data. The NPP is the difference between the gross primary productivity (GPP) and the autotrophic respiration of plants. It almost equals the negative NEE, but excludes the heterotrophic respiration. Lu et al. (2009) built up the applied NPP dataset, using the high-resolution remote sensing SPOT-VEGTATION NDVI satellite data and a Monteithtype parametric NPP model. The annual database spans the period of 1998 to 2002. Figure 7 illustrates the climatological NPP distribution over the Heihe River basin obtained from remote sensing, CTL, and IRR from 1998 to 2002. The high-level NPP occurring in the remote sensing imagery over the middle reaches (Fig. 7a) corresponded to irrigated croplands, as shown in Fig. 3. Furthermore, the retrieved 


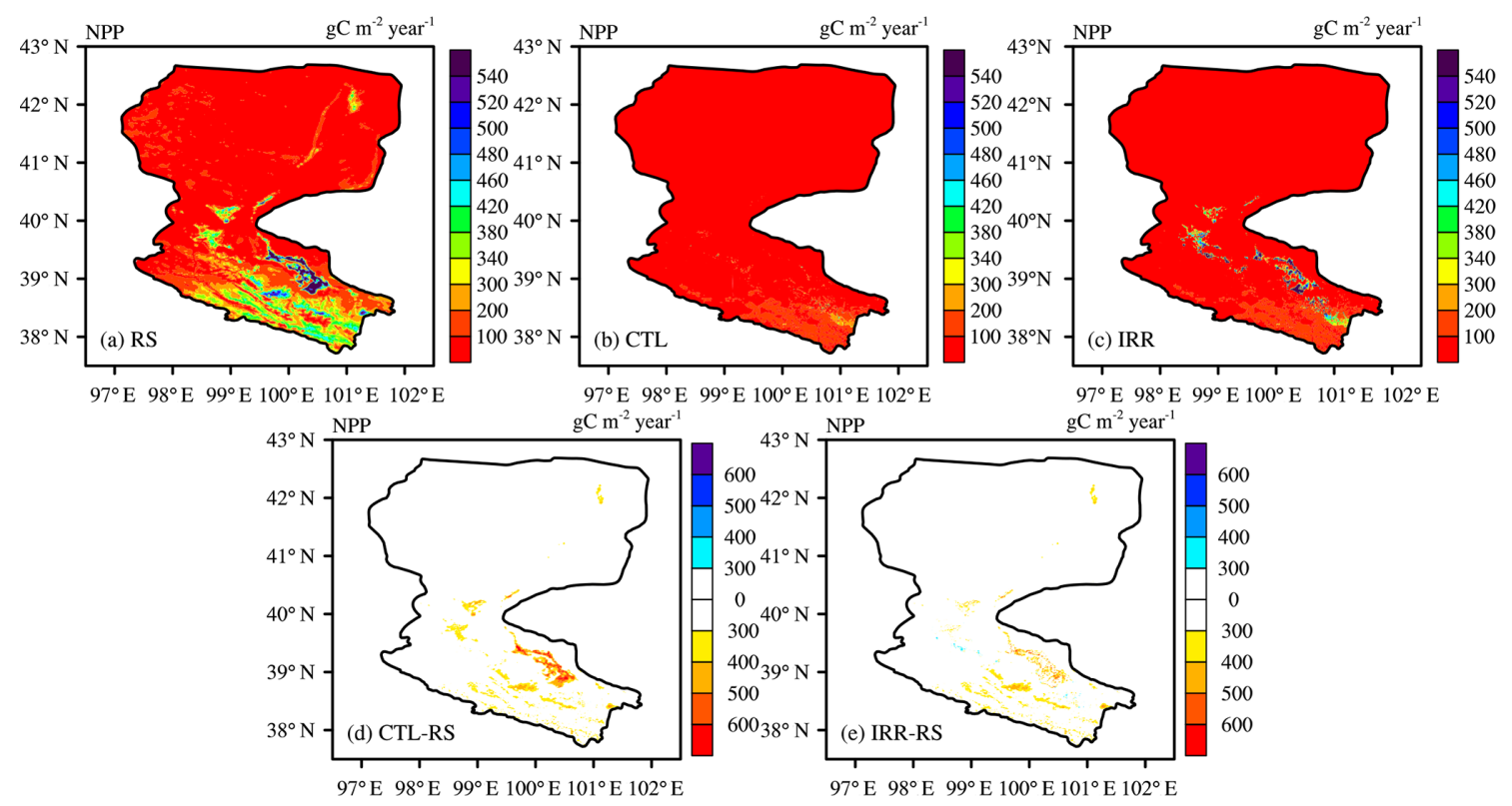

Figure 7. Climatological NPP distribution from 1998 to 2002 over the Heihe River basin obtained from (a) remote sensing, (b) CTL, (c) IRR, (d) CTL remote sensing, and (e) IRR remote sensing.

arctic grass NPP in the upstream region was also relatively high. Figure $7 \mathrm{~b}$, presenting the CTL results, displays a very low NPP (less than $200 \mathrm{gC} \mathrm{m}^{-2} \mathrm{yr}^{-1}$ ) across the entire Heihe River basin. However, when intense irrigation took place, a high-level NPP emerges in the IRR model over the middle stream (Fig. 7c), consistent with the remote sensing dataset. The comparison demonstrates the model's ability to simulate NEE over irrigated areas and to establish the significant effects of irrigation on NEE. The CTL and IRR models could not reproduce the high-level NPP in the upstream region, indicating that the CLM needs further modifications to improve its predictions for arctic regions.

\subsection{The effects of irrigation on land—atmosphere fluxes}

Section 4.2 validated the CLM4.5 when a well-developed irrigation module was combined with a high-quality irrigation dataset to reproduce the land-atmosphere interactions. We then studied the effects of irrigation on the LH, SH, and NEE utilizing high-resolution results obtained from the IRR and CTL runs. Figure 8 displays the differences between IRR and CTL climatic spatial patterns of the LH, SH, and NEE during the spring, summer, and autumn months, averaged for the 1981-2013 period. Figure 8a to c demonstrate that the effects irrigation produced on $\mathrm{LH}$ correspond to an enhanced LH (or ET) occurring over most of the irrigated areas. During summer, the response to irrigation was prominent over a vast zone of the middle reaches, with the LH locally increasing by $\sim 100 \mathrm{~W} \mathrm{~m}^{-2}$ (or $\sim 3.5 \mathrm{~mm} \mathrm{day}^{-1}$ for ET). The consequences during spring and autumn were less important, producing a $\mathrm{LH}$ increase of $10-30$ and $20-40 \mathrm{~W} \mathrm{~m}^{-2}$, respec- tively over the middle reaches. The LH intensification is attributed to increased evaporation from a wetted soil surface and enhanced ET from crops subjected to less water stress. The LH absorbs more energy from the land, the crop temperature cools, and the SH from land to atmosphere is correspondingly reduced. The process is shown in Fig. $8 \mathrm{~d}$ to $\mathrm{f}$. The $\mathrm{SH}$ is lessened during the summer over a large irrigated area of the midstream Heihe Basin in conjunction with LH. The reduction reaches $\sim 60 \mathrm{~W} \mathrm{~m}^{-2}$. The $\mathrm{SH}$ reduction is about 30 to $60 \mathrm{~W} \mathrm{~m}^{-2}$ during the spring, with a very weak effect during autumn (less than $20 \mathrm{~W} \mathrm{~m}^{-2}$ ). Figures $7 \mathrm{i}$ to $8 \mathrm{~g}$ exhibit the differences in NEE for three seasons. During autumn, when the crop photosynthesis is weak, there is little difference between the IRR and CTL model results (Fig. 8i). However, the effects of irrigation on NEE diverged significantly during the summer and spring months. This was because less water stress induced by irrigation enhanced the GPP and crop respiration. In the growth phase of planting and leaf emergence during the spring months, the crop leaves were not fully grown and generated a relatively low rate of photosynthesis. The increase in respiration caused by irrigation was higher than that of GPP, leading to a positive change of NEE (e.g., $0.4-0.8 \mathrm{gC} \mathrm{m}^{-2}$ day $^{-1}$; the positive direction indicating a transfer of carbon from land to atmosphere) over most of the middle irrigated reaches of the Heihe River basin. During summer, when the crops shift from the leaf emergence phase to the grain fill phase, the leaf area index (LAI) and photosynthesis rate are at their maximum for the year. Therefore, after irrigation was included in the models, the GPP increase could become higher than that of respiration, generating a negative change of NEE (less than $-0.8 \mathrm{gC} \mathrm{m}^{-2} \mathrm{day}^{-1}$; the 

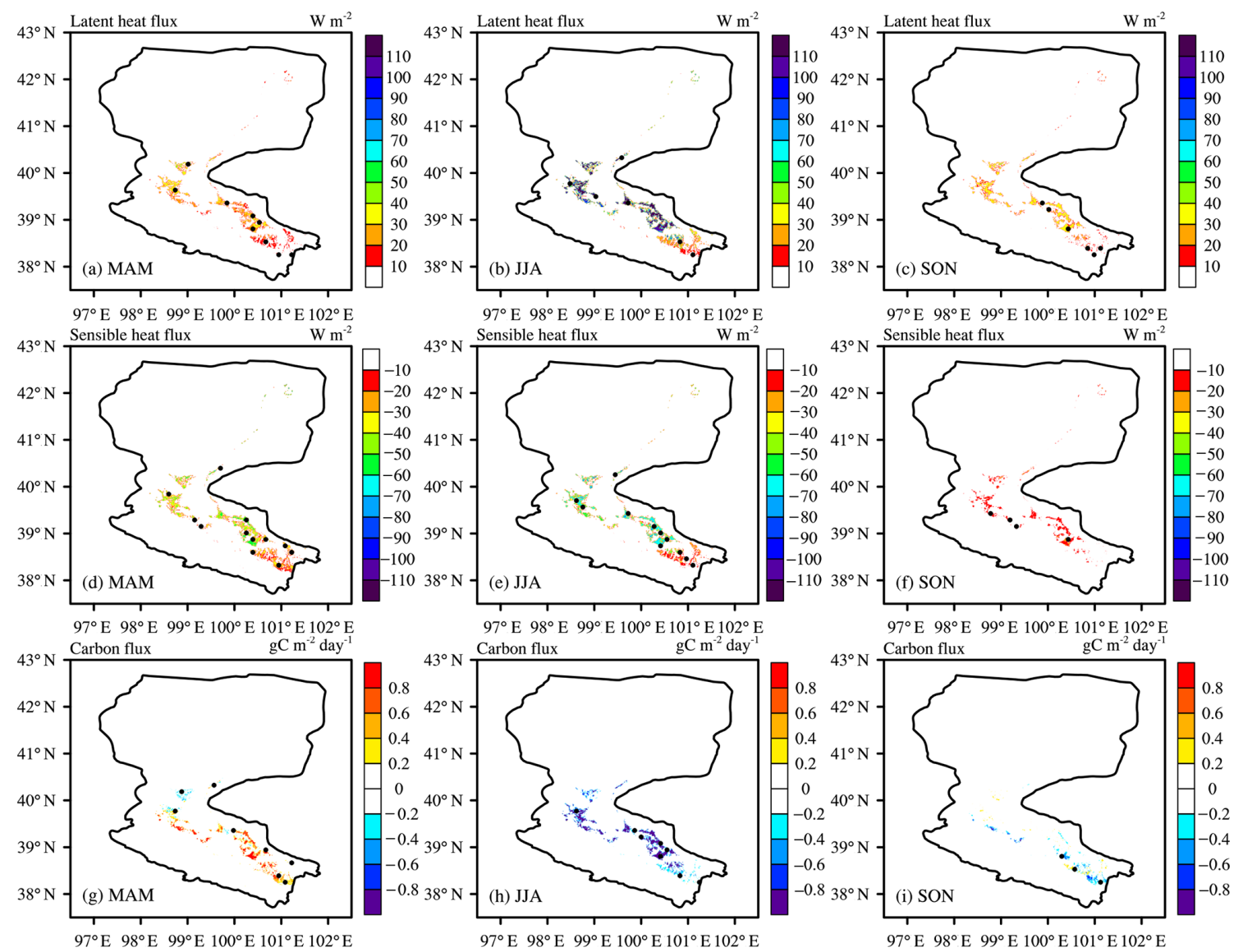

Figure 8. Climatic spatial pattern of (a-c) latent heat flux, (d-f) sensible heat flux, and (g-i) carbon flux differences between IRR and CTL in (a, d, g) spring, (b, e, h) summer, and (c, f, i) autumn, averaged from 1981 to 2013. The dots represent the area that passed the Student's $t$ test at a $95 \%$ confidence level.

negative change indicates that the land ecosystem fixed more carbon from atmospheric $\mathrm{CO}_{2}$ ).

Scatter plots, displayed in Fig. 9, show the differences in fluxes (LH, SH, and NEE) between the IRR and CTL models against the irrigation rate during spring, summer, and autumn. The fluxes and irrigation rates were averaged over the 1981-2013 period; each dot represents an irrigated model grid cell of the Heihe River basin. Figure 9a-c present the relationship between $\triangle \mathrm{LH}$ (LH between IRR and CTL) and irrigation rate. During the spring, when the irrigation rate is less than $2 \mathrm{~mm} \mathrm{day}^{-1}$, the $\Delta \mathrm{LH}$ values increase rapidly with the augmentation of irrigated water usage. However, when the irrigation rate is greater than $2 \mathrm{~mm} \mathrm{day}^{-1}$, the $\Delta \mathrm{LH}$ increase disappears. This is related to the water condition meeting the need of potential ET, when excessive irrigation would no longer produce an ET increase. A similar process occurred during summer and autumn (Fig. 9b and c), but the irrigation rate thresholds increased from 2 to $\sim 4 \mathrm{~mm}_{\text {day }}{ }^{-1}$. Figure $9 \mathrm{~d}-\mathrm{f}$ display decreasing $\Delta \mathrm{SH}$ ( $\mathrm{SH}$ between IRR and CTL) values correlated with an increase in the irrigation rate; the values are similar for the three seasons. However, $\Delta \mathrm{SH}$ remains constant $\left(\sim-60 \mathrm{~W} \mathrm{~m}^{-2}\right.$ for spring, $\sim-80 \mathrm{~W} \mathrm{~m}^{-2}$ for summer, and $\sim-20 \mathrm{~W} \mathrm{~m}^{-2}$ for autumn) when the irrigation rate is greater than $\sim 5 \mathrm{~mm} \mathrm{day}^{-1}$. Figure $9 \mathrm{~g}-\mathrm{i}$ also present a positive correlation between the $\triangle$ NEE (NEE between IRR and CTL) values and irrigation rate during the spring, with the irrigation rate increasing from 0 to $5 \mathrm{~mm} \mathrm{day}^{-1}$, corresponding to $\triangle \mathrm{NEE}$ values ranging from 0 to $1.5 \mathrm{gC} \mathrm{m}^{-2} \mathrm{day}^{-1}$; this once again demonstrates the stronger effects of irrigation on crop respiration during spring relative to GPP. In contrast, during summer (Fig. 9h), when the irrigation rate goes from 0 to $5 \mathrm{~mm} \mathrm{day}^{-1}$, the $\triangle \mathrm{NEE}$ varies from 0 to $-1.5 \mathrm{gC}^{-2} \mathrm{day}^{-1}$, indicating that the effect of irrigation on GPP is stronger than it is on respiration so that the $\triangle \mathrm{NEE}$ is negatively affected (more carbon is fixed by crop) during the summer. There is no clear correlation between $\triangle \mathrm{NEE}$ and the irrigation rate during autumn (Fig. 9i). The $\triangle$ NEE values can augment or diminish when the irrigation usage is intensified.

One of the important findings above is the threshold of $5 \mathrm{~mm} \mathrm{day}^{-1}$ for irrigation rate, above which the effects of irrigation on LH and SH do not change considerably. This is closely related to the semiarid climate of the basin. Over the middle reaches where typical continental climate domi- 

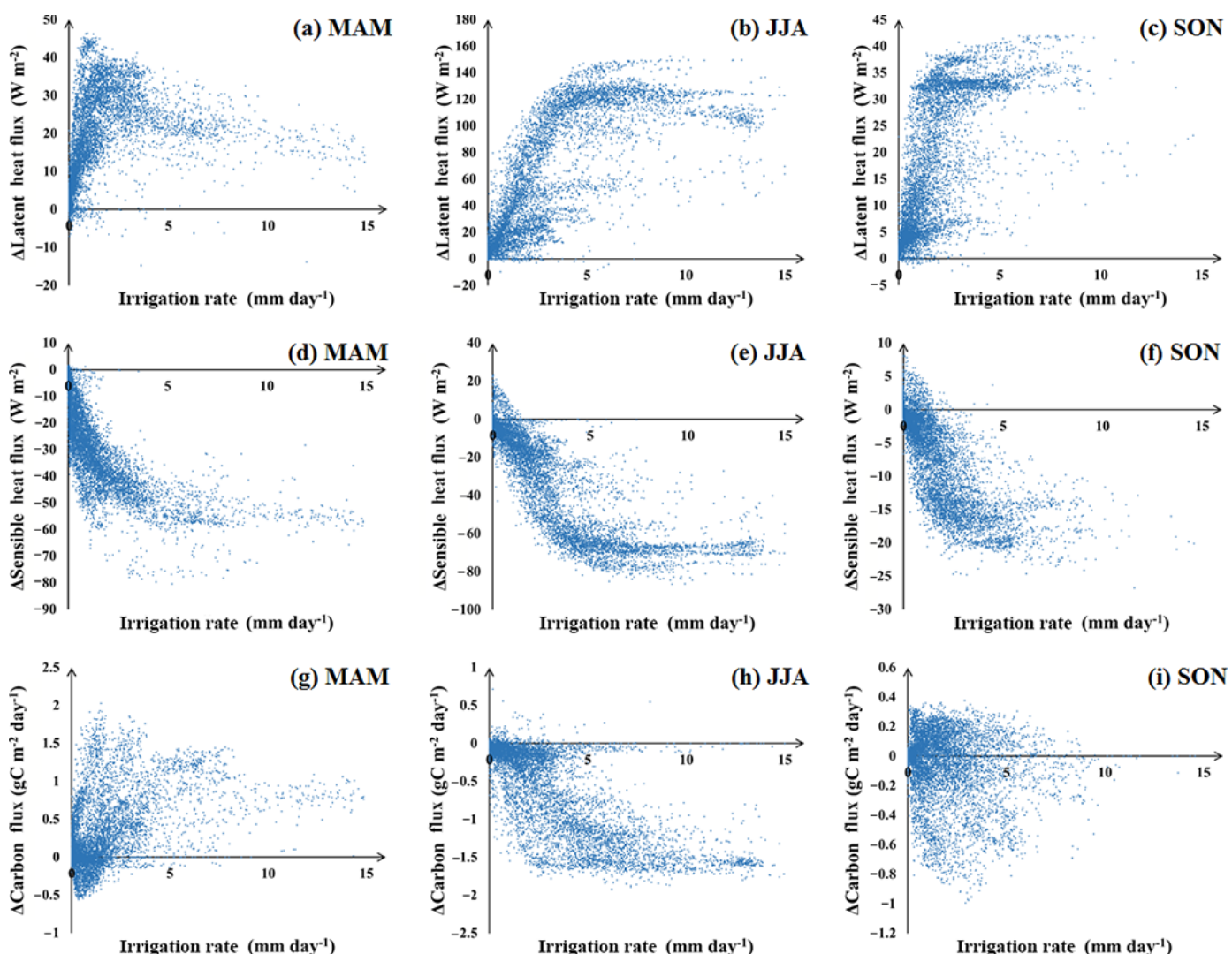

Figure 9. Differences in (a-c) latent heat flux, $(\mathbf{d}-\mathbf{f})$ sensible heat flux, and $(\mathbf{g}-\mathbf{i})$ carbon flux between IRR and CTL models versus the irrigation rate in $(\mathbf{a}, \mathbf{d}, \mathbf{g})$ spring, $(\mathbf{b}, \mathbf{e}, \mathbf{h})$ summer, and $(\mathbf{c}, \mathbf{f}, \mathbf{i})$ autumn.

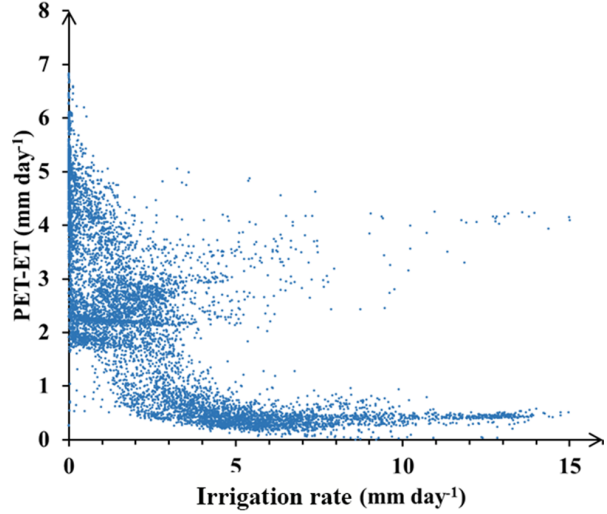

Figure 10. Differences in potential and actual evapotranspiration versus the irrigation rate in summer.

nates, precipitation is scarce and temperature is high during the growing season. The most controlling factor for actual ET is water availability. Therefore, when the water demand for potential ET (PET) is satisfied with irrigation, the actual ET and LH rapidly increase and the SH correspondingly decreases. When the irrigation rate exceeds a certain threshold, $\sim 5 \mathrm{~mm} \mathrm{day}^{-1}$ in this study, the water demand of PET is fully satisfied and the controlling factor of actual ET converts from water availability to energy availability. Thus, the LH and SH are no more sensitive to the increased water supply when irrigation rate exceeds $\sim 5 \mathrm{~mm}$ day $^{-1}$. It also explains why the irrigation threshold in summer is higher than it is in spring and autumn (shown in Fig. 9): the water demand needed to elevate the actual ET to the PET is highest in summer due to the hot weather. To demonstrate the analysis above, a scatter plot (Fig. 10) showing the differences between the PET and actual ET (PET-ET) against the irrigation rate in summertime was displayed. The ET was obtained from the IRR simulation, and the PET was estimated from the near-surface temperature (also produced by the IRR) via the method of Thornthwaite (Thornthwaite, 1948). The Thornthwaite method was chosen here because the only input variable it needs to calculate the PET is the near-surface temperature, a highly credible variable reproduced by the land surface model. A systematic error (about $-1.5 \mathrm{~mm} \mathrm{day}^{-1}$ ) in the Thornthwaite method (Hashemi and Habibian, 1979; Pereira and De Camargo, 1989) has been removed in Fig. 10 to prevent the PET-ET from being negative. Figure 10 shows that when irrigation rate is less than $\sim 5 \mathrm{~mm} \mathrm{day}^{-1}$, the PET-ET decreases when irrigation increases, and when the irrigation rate exceeds $\sim 5 \mathrm{~mm} \mathrm{day}^{-1}$, the PET-ET tends to be zero, demon- 

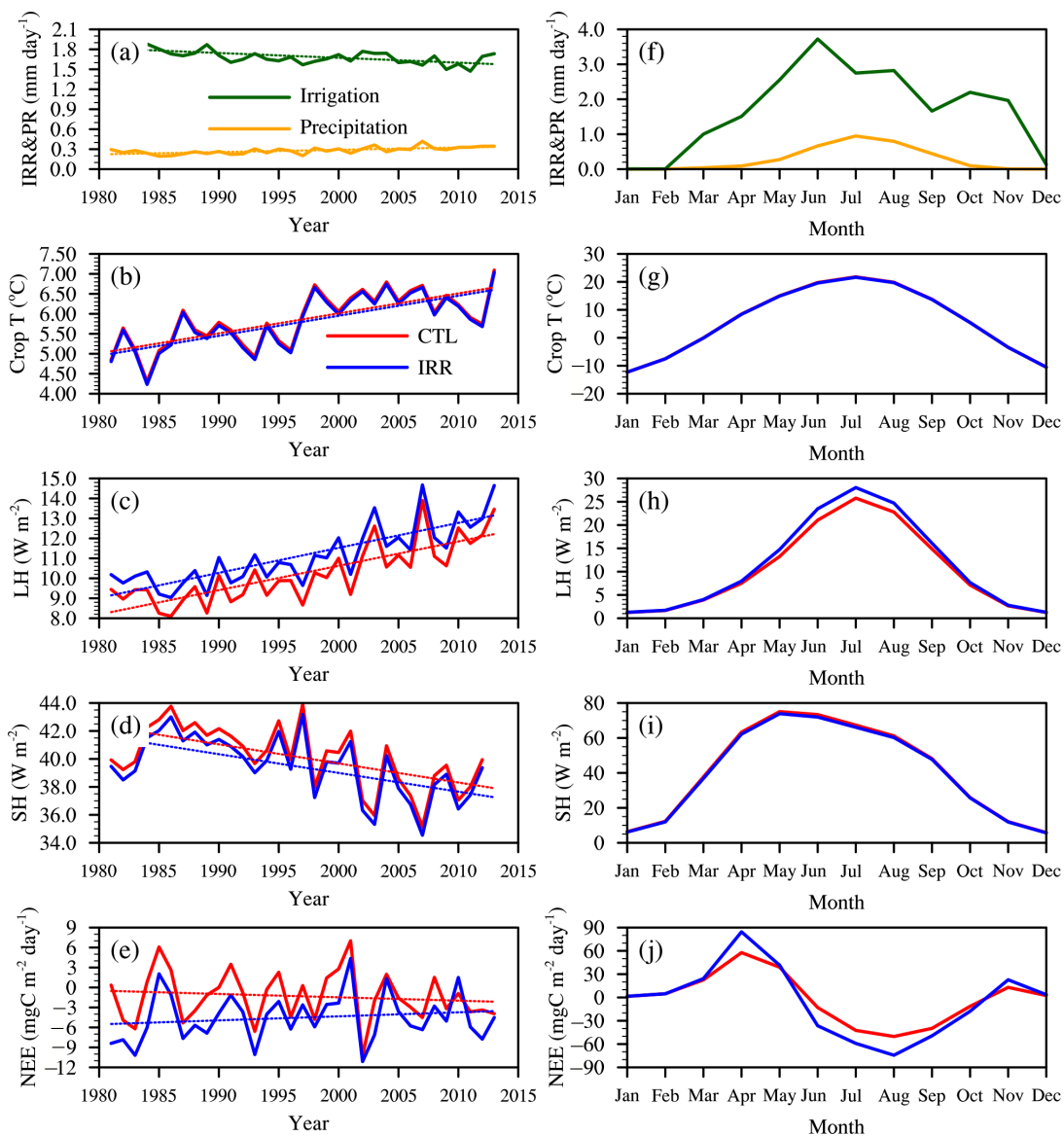

Figure 11. Time evolution plots of (a-e) annual and (f-j) seasonal (a, f) irrigation and precipitation, (b, g) crop temperature, (c, h) latent heat flux, $(\mathbf{d}, \mathbf{i})$ sensible heat flux, and $(\mathbf{e}, \mathbf{j})$ carbon heat flux, averaged over all crop grids of the Heihe River basin.

strating that the water demand of PET can be satisfied with an irrigation rate of $\sim 5 \mathrm{~mm}$ day $^{-1}$.

We then investigated the interannual and seasonal variability of land-atmosphere fluxes caused by irrigation. Figure $11 \mathrm{a}-\mathrm{e}$ show a time evolution of the annual irrigation rate, precipitation, crop temperature (CT), and some landatmosphere fluxes obtained from 1981 to 2013. The data were averaged over all crop grid cells. Figure 11a illustrates a slightly reduced annual irrigation rate from 1.8 to $1.6 \mathrm{~mm} \mathrm{day}^{-1}$ from 1981 to 2013 , whereas the precipitation rate increased moderately from 0.3 to $0.5 \mathrm{~mm} \mathrm{day}^{-1}$. The total water input (irrigation plus precipitation) to the cropland has been almost constant over the last 30 years. Figure $11 \mathrm{~b}$ reveals a significant increasing trend of annual CT directly attributed to global warming, whereas Fig. 11c illustrates an important augmentation in annual LH during 1981-2013 that could not be explained by steady irrigation or precipitation trends (Fig. 11a). In contrast, the increasing LH trend could be linked to the growing CT (shown in Fig. 11b). Therefore, the interannual LH trend was influenced more by the temperature (radiation limitation) than the irrigation rate (soil moisture limitation). In Fig. 11d, the SH time evolution plot also displays a significant decreasing trend linked to temperature augmentation. Figure 11e presents the negative consequence of irrigation on the annual NEE (e.g., more carbon is transferred from atmosphere to land). Furthermore, the NEE increases during the IRR modeling and decreases in the CTL modeling, resulting in a $\triangle$ NEE augmentation (IRR-CTL) from 1981 to 2013. In 2010, the NEE in IRR became even higher than that in the CTL. Figure 11f-j present the seasonal variations in annual irrigation, precipitation, CT, and land-atmosphere fluxes. The data obtained from 1981 to 2013 were averaged over all crop grid cells in the Heihe River basin. The LH and SH response to irrigation is substantial in the growth season occurring from April to October (Figs. 11h and 10i), whereas it is negative for NEE from May to September, and positive in March, April, and November (Fig. 11j)

Figure 12a shows the temporal correlation coefficients $(R)$ obtained for the irrigation rate versus the differences in landatmosphere fluxes for spring, summer, and autumn $(\Delta \mathrm{LH}$, $-\Delta \mathrm{SH}$, and $-\Delta \mathrm{NEE}$; the negative signs before $\Delta \mathrm{SH}$ and $\Delta$ NEE were applied to make $R$ positive). The correlations between the irrigation rate and turbulent flux variations were 

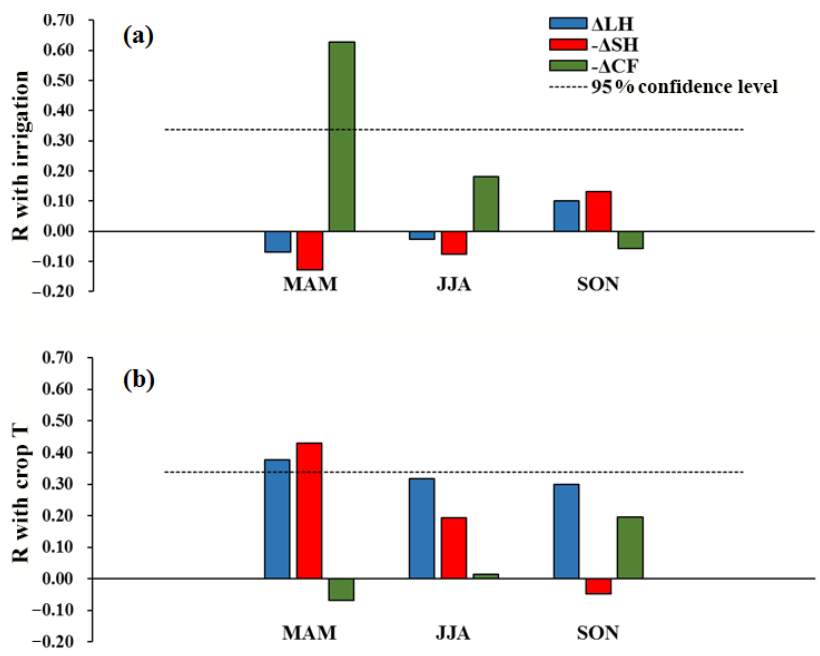

Figure 12. (a) Temporal correlation coefficients between the irrigation rate and $\Delta \mathrm{LH},-\Delta \mathrm{SH}$, and $-\Delta \mathrm{NEE}$ over spring, summer, and autumn and (b) temporal correlation coefficients between the crop temperature and $\Delta \mathrm{LH},-\Delta \mathrm{SH}$, and $-\Delta \mathrm{NEE}$ over spring, summer, and autumn.

very poor and did not pass the Student's $t$ test at a $95 \%$ confidence level. This again proves that irrigation significantly modified the land-atmosphere fluxes for each year, but the interannual variability did not have much impact on the fluxes. However, for the spring NEE, the obtained $R$ value was 0.6 and passed the Student's $t$ test, suggesting that more irrigation water applied during the spring can cause more carbon absorption by the crop. It is attributed to an earlier associated leaf emergence phase induced by better water conditions for the crop. The correlation coefficient $(R \sim 0.4)$ between the CT (from IRR) and the differences in fluxes passed the significance test and is reproduced in Fig. 12b, which shows that the $\Delta \mathrm{LH}$ and $\Delta \mathrm{SH}$ values are associated with $\mathrm{CT}$ during the spring period. Figures 9 and 10 demonstrate that the effects of irrigation on the land-atmosphere systems are not solely linked to irrigation amount; other factors (such as global warming) also play important roles that cannot be ignored.

\section{Conclusions and discussion}

In this study, we performed two modeling experiments (CTL and IRR) over the Heihe River basin of China conducted by improved CLM4.5 with high-quality irrigation data collected from 1981 to 2013 to quantify the effects of irrigation on land-atmosphere fluxes. Comparing the model results to flux measurements obtained from remote sensing demonstrated their reliability. The consequences of irrigation on $\mathrm{LH}, \mathrm{SH}$, and NEE were analyzed based on the simulation results, and we studied the relation between the fluxes and the intensity of irrigation.
The principal conclusions from our investigations are as follows: (1) the effects of irrigation on the LH and SH parameters are strongest during summer, with an increase in LH of $\sim 100 \mathrm{~W} \mathrm{~m}^{-2}$ and a decrease in SH of $\sim 60 \mathrm{~W} \mathrm{~m}^{-2}$ over intensely irrigated areas. However, the effects of irrigation are less important during spring and autumn because of a lesser application of irrigated water. (2) When the irrigation rate is less than $5 \mathrm{~mm}$ day $^{-1}$, the LH generally increases, and the $\mathrm{SH}$ is reduced with an increasing irrigation rate. When the irrigation rate exceeds the threshold of $5 \mathrm{~mm}$ day $^{-1}$, its effect on LH and SH is subdued. (3) During spring, irrigation produces more carbon transferred from the land to the atmosphere, increasing NEE by $0.4-0.8 \mathrm{gC} \mathrm{m}^{-2} \mathrm{day}^{-1}$, whereas during summer, irrigation facilitates the crop fixation of carbon from atmospheric $\mathrm{CO}_{2}$, decreasing NEE by $\sim 0.8 \mathrm{gC} \mathrm{m}^{-2}$ day $^{-1}$. (4) The results of irrigation on land-atmosphere fluxes are also linked to other parameters (especially the temperature) that also play important roles in LH, SH, and NEE.

The depletion of terrestrial water storage in the basin needs to be stressed here. In Fig. 4, both the simulation IRR and GRACE satellite reflect a water loss of about $2 \mathrm{~mm}$ per year. This depletion is critical to the inland basin, where mountainous glacial water and groundwater supply play essential roles in irrigation. To deal with the water depletion, it is necessary to determine balances between economic development and water exploitation and between surface water diversion and groundwater pumping. Wu et al. (2016) have set up some meaningful studies for optimizing conjunctive use of surface water and groundwater for irrigation to address human-nature water conflicts. More research should focus on the future problem of water resources in the basin.

Our study demonstrates that irrigation plays an essential role in the exchange of water, energy, and carbon from the land to the atmosphere. Limitations and assumptions inherent to the CLM4.5 and atmospheric forcing data can bring some uncertainties to our results (Bonan et al., 2011, 2013; Mao et al., 2012; Wang et al., 2013). Our module currently cannot distinguish between sprinkler irrigation, flooding irrigation, and drip irrigation, while in reality there should be different ways to treat for different crop types. This may lead to a slight overestimation of water reaching the topsoil. Moreover, there is currently no scheme for the reservoir in the basin for irrigation purposes, and the groundwater pumping is assumed to be executed at the location where it is consumed. These simple and unrealistic assumptions will certainly create some uncertainties in our results and show the future directions for model development. However, our results provide a high level of confidence because (1) CLM4.5 is one of the world's most advanced and widely used land models, verified especially for its ability to reproduce land-atmosphere fluxes; (2) the simulation resolution is high enough $(1 \mathrm{~km})$ to show the patchwork of irrigated areas, and the input irrigation database is comprehensible and reliable; and (3) there is consistency between the simulated model output and the observation of remote sensing. Another 
limit is that the high-quality irrigation data are available for this particular catchment, but not at continental scale. This limits the applicability of this experiment to larger domains before we produce high-resolution irrigation datasets over a larger scale.

Future studies should focus on three aspects. First, other important land-atmosphere fluxes, such as the momentum, nitrogen, and oxygen fluxes are also related to irrigation and deserved to be investigated further. Secondly, irrigation may modify the climate, affecting natural processes and anthropogenic activities on land. This land-atmosphere interaction needs to be explored using regional or global climate models. Third, this study conducted a high-resolution modeling over a typical irrigated basin. The ultimate goal is to perform highresolution modeling on a continental or even global scale using the advanced power of supercomputers.

\section{Code availability}

The model code is available upon request. Please contact Zhenghui Xie at zxie@lasg.iap.ac.cn.

Competing interests. The authors declare that they have no conflict of interest.

Acknowledgements. This work was jointly funded by the Key Research Program of Frontier Sciences, Chinese Academy of Sciences (grant no. QYZDY-SSW-DQC012) and by the National Natural Science Foundation of China (grant no. 41575096). The irrigation dataset was provided by the Cold and Arid Regions Science Data Center at Lanzhou (http://www.heihedata.org/data/ 66322216-b99a-4c54-a130-a0c3ef0ed972). The atmospheric forcing data were obtained through the Data Assimilation and Modeling Center for Tibetan Multi-spheres, Institute of Tibetan Plateau Research, Chinese Academy of Sciences (http://westdc. westgis.ac.cn/data/7a35329c-c53f-4267-aa07-e0037d913a21).

The databases from the ET and NPP remote sensing data were provided by the Cold and Arid Regions Science Data Center at Lanzhou, China (http://westdc.westgis.ac.cn). We would like to thank Xing Yuan and Xiangjun Tian for their assistance with this work and their helpful discussions. We also thank Guoyong Leng and the other anonymous reviewer for the helpful comments that improved the paper.

Edited by: S. Baidya Roy

Reviewed by: G. Leng and one anonymous referee

\section{References}

Anderson, M., Norman, J., Diak, G., Kustas, W., and Mecikalski, J.: A two-source time-integrated model for estimating surface fluxes using thermal infrared remote sensing, Remote Sens. Environ., 60, 195-216, 1997.
Bastiaanssen, W., Noordman, E., Pelgrum, H., Davids, G., and Allen, R.: SEBAL for spatially distributed ET under actual management and growing conditions, J. Irrig. Drain. Eng.-ASCE, 131, 85-93, 2005.

Bindoff, N. L., Stott, P. A., AchutaRao, K. M., Allen, M. R., Gillett, N., Gutzler, D., Hansingo, K., Hegerl, G., Hu, Y., Jain, S., Mokhov, I. I., Overland, J., Perlwitz, J., Sebbari, R., and Zhang, $\mathrm{X}$.: Detection and attribution of climate change: From global to regional, in: Climate Change 2013: The Physical Science Basis. IPCC Working Group I Contribution to AR5, Chapter 10, Cambridge University Press, Cambridge, 2013.

Bonan, G. B., Lawrence, P. J., Oleson, K. W., Levis, S., Jung, M., Reichstein, M., Lawrence, D. M., and Swenson, S. C.: Improving canopy processes in the Community Land Model version 4 (CLM4) using global flux fields empirically inferred from FLUXNET data, J. Geophys. Res.-Biogeo., 116, G02014, doi:10.1029/2010JG001593, 2011.

Bonan, G. B., Hartman, M. D., Parton, W. J., and Wieder, W. R.: Evaluating litter decomposition in earth system models with long-term litterbag experiments: an example using the Community Land Model version 4 (CLM4), Glob. Change Biol., 19, 957-974, 2013.

Boucher, O., Myhre, G., and Myhre, A.: Direct human influence of irrigation on atmospheric water vapour and climate, Clim. Dynam., 22, 597-603, doi:10.1007/s00382-004-0402-4, 2004.

Chen, F. and Xie, Z. H.: Effects of interbasin water transfer on regional climate: A case study of the Middle Route of the South-toNorth Water Transfer Project in China, J. Geophys. Res.-Atmos., 115, D11112, doi:10.1029/2009jd012611, 2010.

Chen, F. and Xie, Z. H.: Effects of crop growth and development on regional climate: a case study over East Asian monsoon area, Clim. Dynam., 38, 2291-2305, doi:10.1007/s00382-011-1125-y, 2012.

Chen, Y., Zhang, D. Q., Sun, Y. B., Liu, X. N., Wang, N. Z., and Savenije, H. H. G.: Water demand management: A case study of the Heihe River Basin in China, Phys. Chem. Earth, 30, 408-419, doi:10.1016/j.pce.2005.06.019, 2005.

Clark, M. P., Fan, Y., Lawrence, D. M., Adam, J. C., Bolster, D., Gochis, D. J., Hooper, R. P., Kumar, M., Leung, L. R., and Mackay, D. S.: Improving the representation of hydrologic processes in Earth System Models, Water Resour. Res., 51, 59295956, 2015a.

Clark, M. P., Nijssen, B., Lundquist, J. D., Kavetski, D., Rupp, D. E., Woods, R. A., Freer, J. E., Gutmann, E. D., Wood, A. W., and Brekke, L. D.: A unified approach for process-based hydrologic modeling: 1. Modeling concept, Water Resour. Res., 51, 24982514, 2015b.

Clark, M. P., Nijssen, B., Lundquist, J. D., Kavetski, D., Rupp, D. E., Woods, R. A., Freer, J. E., Gutmann, E. D., Wood, A. W., and Gochis, D. J.: A unified approach for process-based hydrologic modeling: 2. Model implementation and case studies, Water Resour. Res., 51, 2515-2542, 2015c.

Cook, B. I., Seager, R., and Miller, R. L.: The impact of devegetated dune fields on North American climate during the late Medieval Climate Anomaly, Geophys. Res. Lett., 38, L14704, doi:10.1029/2011GL047566, 2011.

Cook, B. I., Shukla, S. P., Puma, M. J., and Nazarenko, L. S.: Irrigation as an historical climate forcing, Clim. Dynam., 44, 1715$1730,2015$. 
Cox, P. M., Betts, R. A., Jones, C. D., Spall, S. A., and Totterdell, I. J.: Acceleration of global warming due to carbon-cycle feedbacks in a coupled climate model, Nature, 408, 184-187, 2000.

Di, Z. H., Xie, Z. H., Yuan, X., Tian, X. J., Luo, Z. D., and Chen, Y. N.: Prediction of water table depths under soil watergroundwater interaction and stream water conveyance, Sci. China Ser. D, 54, 420-430, doi:10.1007/s11430-010-4050-8, 2011.

Douglas, E. M., Niyogi, D., Frolking, S., Yeluripati, J., Pielke, R. A., Niyogi, N., Vörösmarty, C., and Mohanty, U.: Changes in moisture and energy fluxes due to agricultural land use and irrigation in the Indian Monsoon Belt, Geophys. Res. Lett., 33, L14403, doi:10.1029/2006GL026550, 2006.

Fan, Y.: Groundwater in the Earth's critical zone: Relevance to large-scale patterns and processes, Water Resour. Res., 51, 30523069, doi:10.1002/2015WR017037, 2015.

Forster, S. and Graf, G.: Impact of irrigation on oxygen flux into the sediment: intermittent pumping by Callianassa subterranea and "piston-pumping" by Lanice conchilega, Mar. Biol., 123, 335346, 1995.

Gent, P. R., Danabasoglu, G., Donner, L. J., Holland, M. M., Hunke, E. C., Jayne, S. R., Lawrence, D. M., Neale, R. B., Rasch, P. J., Vertenstein, M., Worley, P. H., Yang, Z. L., and Zhang, M. H.: The Community Climate System Model Version 4, J. Climate, 24, 4973-4991, doi:10.1175/2011jcli4083.1, 2011.

Haddeland, I., Lettenmaier, D. P., and Skaugen, T.: Effects of irrigation on the water and energy balances of the Colorado and Mekong river basins, J. Hydrol., 324, 210-223, 2006.

Hashemi, F. and Habibian, M.: Limitations of temperature-based methods in estimating crop evapotranspiration in arid-zone agricultural development projects, Agr. Meteorol., 20, 237-247, 1979.

Hurrell, J. W., Holland, M. M., Gent, P. R., Ghan, S., Kay, J. E., Kushner, P. J., Lamarque, J. F., Large, W. G., Lawrence, D., Lindsay, K., Lipscomb, W. H., Long, M. C., Mahowald, N., Marsh, D. R., Neale, R. B., Rasch, P., Vavrus, S., Vertenstein, M., Bader, D., Collins, W. D., Hack, J. J., Kiehl, J., and Marshall, S.: The Community Earth System Model A Framework for Collaborative Research, B. Am. Meteorol. Soc., 94, 1339-1360, doi:10.1175/Bams-D-12-00121.1, 2013.

Kendig, S., Rupe, J., and Scott, H.: Effect of irrigation and soil water stress on densities of Macrophomina phaseolina in soil and roots of two soybean cultivars, Plant Dis., 84, 895-900, 2000.

Kluzek, E.: CESM research tools: CLM4 in CESM1. 0.4 user's guide documentation, National Centers for Atmospheric Research, Boulder, 2012.

Lawrence, D. M., Oleson, K. W., Flanner, M. G., Thornton, P. E., Swenson, S. C., Lawrence, P. J., Zeng, X., Yang, Z. L., Levis, S., and Sakaguchi, K.: Parameterization improvements and functional and structural advances in version 4 of the Community Land Model, J. Adv. Model. Earth Sy., 3, M03001, doi:10.1029/2011MS00045, 2011.

Leng, G., Huang, M., Tang, Q., and Leung, L. R.: A modeling study of irrigation effects on global surface water and groundwater resources under a changing climate, J. Adv. Model. Earth Sy., 7, 1285-1304, 2015.

Leng, G. Y., Huang, M. Y., Tang, Q. H., Sacks, W. J., Lei, H. M., and Leung, L. R.: Modeling the effects of irrigation on land surface fluxes and states over the conterminous United States: Sensitivity to input data and model parameters, J. Geophys. Res.-Atmos., 118, 9789-9803, doi:10.1002/Jgrd.50792, 2013.

Leng, G. Y., Huang, M. Y., Tang, Q. H., Gao, H. L., and Leung, L. R.: Modeling the Effects of Groundwater-Fed Irrigation on Terrestrial Hydrology over the Conterminous United States, J. Hydrometeorol., 15, 957-972, doi:10.1175/Jhm-D-13-049.1, 2014.

Levis, S., Bonan, G. B., Kluzek, E., Thornton, P. E., Jones, A., Sacks, W. J., and Kucharik, C. J.: Interactive crop management in the Community Earth System Model (CESM1): Seasonal influences on land-atmosphere fluxes, J. Climate, 25, 4839-4859, 2012.

Li, X., Lu, L., Cheng, G. D., and Xiao, H. L.: Quantifying landscape structure of the Heihe River Basin, north-west China using FRAGSTATS, J. Arid Environ., 48, 521-535, doi:10.1006/jare.2000.0715, 2001.

Li, X., Cheng, G. D., Liu, S. M., Xiao, Q., Ma, M. G., Jin, R., Che, T., Liu, Q. H., Wang, W. Z., Qi, Y., Wen, J. G., Li, H. Y., Zhu, G. F., Guo, J. W., Ran, Y. H., Wang, S. G., Zhu, Z. L., Zhou, J., Hu, X. L., and Xu, Z. W.: Heihe Watershed Allied Telemetry Experimental Research (HiWATER): Scientific Objectives and Experimental Design, B. Am. Meteorol. Soc., 94, 1145-1160, doi:10.1175/Bams-D-12-00154.1, 2013.

Lindsay, K., Bonan, G. B., Doney, S. C., Hoffman, F. M., Lawrence, D. M., Long, M. C., Mahowald, N. M., Moore, J. K., Randerson, J. T., and Thornton, P. E.: Preindustrial-Control and Twentieth-Century Carbon Cycle Experiments with the Earth System Model CESM1(BGC), J. Climate, 27, 8981-9005, doi:10.1175/Jcli-D-12-00565.1, 2014.

Liu, S., Xie, Z., and Zeng, Y.: Discharge Estimation for an Ungauged Inland River in an Arid Area Related to Anthropogenic Activities: A Case Study of Heihe River Basin, Northwestern China, Advances in Meteorology, 2016, 6716501, doi:10.1155/2016/6716501, 2016.

Lobell, D. B., Bonfils, C. J., Kueppers, L. M., and Snyder, M. A.: Irrigation cooling effect on temperature and heat index extremes, Geophys. Res. Lett., 35, L09705, doi:10.1029/2008GL034145, 2008.

Lu, L., Li, X., and Cheng, G. D.: Landscape evolution in the middle Heihe River Basin of north-west China during the last decade, J. Arid Environ., 53, 395-408, doi:10.1006/jare.2002.1032, 2003.

Lu, L., Li, X., Veroustraete, F., Kang, E., and Wang, J.: Analysing the forcing mechanisms for net primary productivity changes in the Heihe River Basin, north-west China, Int. J. Remote Sens., 30, 793-816, 2009.

Mao, J., Thornton, P. E., Shi, X., Zhao, M., and Post, W. M.: Remote Sensing Evaluation of CLM4 GPP for the Period 2000-09*, J. Climate, 25, 5327-5342, 2012.

Meijninger, W. and De Bruin, H.: The sensible heat fluxes over irrigated areas in western Turkey determined with a large aperture scintillometer, J. Hydrol., 229, 42-49, 2000.

Norman, J. M., Kustas, W. P., and Humes, K. S.: Source approach for estimating soil and vegetation energy fluxes in observations of directional radiometric surface temperature, Agr. Forest Meteorol., 77, 263-293, 1995.

Oleson, K., Lawrence, D., Bonan, G., Drewniak, B., Huang, M., Koven, C., Levis, S., Li, F., Riley, W., and Subin, Z.: Technical Description of version 4.5 of the Community Land Model (CLM), NCAR, National Center for Atmospheric Research (NCAR) Boulder, Colorado, 2013. 
Oweis, T. and Hachum, A.: Water harvesting and supplemental irrigation for improved water productivity of dry farming systems in West Asia and North Africa, Agr. Water Manage., 80, 57-73, 2006.

Pereira, A. R. and De Camargo, Â. P.: An analysis of the criticism of Thornthwaite's equation for estimating potential evapotranspiration, Agr. Forest Meteorol., 46, 149-157, 1989.

Pokhrel, Y., Hanasaki, N., Koirala, S., Cho, J., Yeh, P. J. F., Kim, H., Kanae, S., and Oki, T.: Incorporating Anthropogenic Water Regulation Modules into a Land Surface Model, J. Hydrometeorol., 13, 255-269, doi:10.1175/Jhm-D-11-013.1, 2012.

Puma, M. J. and Cook, B. I.: Effects of irrigation on global climate during the 20th century, J. Geophys. Res.-Atmos., 115, D16120, doi:10.1029/2010jd014122, 2010.

Qi, S. Z. and Luo, F.: Water environmental degradation of the Heihe River Basin in arid northwestern China, Environ. Monit. Assess., 108, 205-215, doi:10.1007/s10661-005-3912-6, 2005.

Ran, Y., Li, X., Lu, L., and Li, Z.: Large-scale land cover mapping with the integration of multi-source information based on the Dempster-Shafer theory, Int. J. Geogr. Inf. Sci., 26, 169-191, 2012.

Sacks, W. J., Cook, B. I., Buenning, N., Levis, S., and Helkowski, J. H.: Effects of global irrigation on the near-surface climate, Clim. Dynam., 33, 159-175, 2009.

Scheer, C., Wassmann, R., Kienzler, K., Ibragimov, N., and Eschanov, R.: Nitrous oxide emissions from fertilized, irrigated cotton (Gossypium hirsutum L.) in the Aral Sea Basin, Uzbekistan: Influence of nitrogen applications and irrigation practices, Soil Biol. Biochem., 40, 290-301, 2008.

Shangguan, W., Dai, Y., Liu, B., Ye, A., and Yuan, H.: A soil particle-size distribution dataset for regional land and climate modelling in China, Geoderma, 171, 85-91, 2012.

Shukla, S. P., Puma, M. J., and Cook, B. I.: The response of the South Asian Summer Monsoon circulation to intensified irrigation in global climate model simulations, Clim. Dynam., 42, 2136, 2014.

$\mathrm{Su}, \mathrm{Z}$. : The Surface Energy Balance System (SEBS) for estimation of turbulent heat fluxes, Hydrol. Earth Syst. Sci., 6, 85-100, doi:10.5194/hess-6-85-2002, 2002.

Tapley, B. D., Bettadpur, S., Watkins, M., and Reigber, C.: The gravity recovery and climate experiment: Mission overview and early results, Geophys. Res. Lett., 31, L09607, doi:10.1029/2004GL019920, 2004.

Thornthwaite, C. W.: An approach toward a rational classification of climate, Geogr. Rev., 38, 55-94, 1948.

Vitousek, P. M., Mooney, H. A., Lubchenco, J., and Melillo, J. M.: Human domination of Earth's ecosystems, Science, 277, 494499, 1997.

Vörösmarty, C. J. and Sahagian, D.: Anthropogenic disturbance of the terrestrial water cycle, Bioscience, 50, 753-765, 2000.
Wang, K., Mao, J., Dickinson, R. E., Shi, X., Post, W. M., Zhu, Z., and Myneni, R. B.: Evaluation of CLM4 solar radiation partitioning scheme using remote sensing and site level FPAR datasets, Remote Sensing, 5, 2857-2882, 2013.

Wu, B., Yan, N., Xiong, J., Bastiaanssen, W., Zhu, W., and Stein, A.: Validation of ETWatch using field measurements at diverse landscapes: A case study in Hai Basin of China, J. Hydrol., 436, 67-80, 2012.

Wu, J. K., Ding, Y., Ye, B., Yang, Q., Zhang, X., and Wang, J.: Spatio-temporal variation of stable isotopes in precipitation in the Heihe River Basin, Northwestern China, Environ. Earth Sci., 61, 1123-1134, doi:10.1007/s12665-009-0432-7, 2010.

Wu, X., Zheng, Y., Wu, B., Tian, Y., Han, F., and Zheng, C.: Optimizing conjunctive use of surface water and groundwater for irrigation to address human-nature water conflicts: A surrogate modeling approach, Agr. Water Manage., 163, 380-392, 2016.

Xie, Z. H., Di, Z. H., Luo, Z. D., and Ma, Q.: A QuasiThree-Dimensional Variably Saturated Groundwater Flow Model for Climate Modeling, J. Hydrometeorol., 13, 27-46, doi:10.1175/Jhm-D-10-05019.1, 2012.

Xie, Z. H., Zeng, N., Wang, H. J., Lin, Z., Tian, X. J., and Jia, B. H.: Past, present and future of the carbon cycle, Natl. Sci. Rev., 1, 18-21, doi:10.1093/nsr/nwt021, 2014.

Yang, K., He, J., Tang, W., Qin, J., and Cheng, C. C.: On downward shortwave and longwave radiations over high altitude regions: Observation and modeling in the Tibetan Plateau, Agr. Forest Meteorol., 150, 38-46, 2010.

Yu, Y., Xie, Z. H., and Zeng, X. B.: Impacts of modified Richards equation on RegCM4 regional climate modeling over East Asia, J. Geophys. Res.-Atmos., 119, 12642-12659, doi:10.1002/2014jd021872, 2014.

Zeng, Y., Xie, Z., Yu, Y., Liu, S., Wang, L., Zou, J., Qin, P., and Jia, B.: Effects of anthropogenic water regulation and groundwater lateral flow on land processes, J. Adv. Model. Earth Sy., 8, 11061131, doi:10.1002/2016MS000646, 2016.

Zeng, Y., Xie, Z., and Zou, J.: Hydrologic and Climatic Responses to Global Anthropogenic Groundwater Extraction, J. Climate, 30, 71-90, doi:10.1175/JCLI-D-16-0209.1, 2017.

Zhong, B., Ma, P., Nie, A., Yang, A., Yao, Y., Lü, W., Zhang, H., and Liu, Q.: Land cover mapping using time series HJ-1/CCD data, Sci. China Ser. D, 57, 1790-1799, 2014.

Zou, J., Xie, Z. H., Yu, Y., Zhan, C. S., and Sun, Q.: Climatic responses to anthropogenic groundwater exploitation: a case study of the Haihe River Basin, Northern China, Clim. Dynam., 42, 2125-2145, doi:10.1007/s00382-013-1995-2, 2014.

Zou, J., Xie, Z. H., Zhan, C. S., Qin, P. H., Sun, Q., Jia, B. H., and Xia, J.: Effects of anthropogenic groundwater exploitation on land surface processes: A case study of the Haihe River Basin, northern China, J. Hydrol., 524, 625-641, doi:10.1016/j.jhydrol.2015.03.026, 2015. 